\title{
Analysis of Changes in Selected Market Structures in Relation to Economic Success
}

\section{Jiri Kraft}

Technical University in Liberec

Studentska 2, 46117 Liberec, Czech Republic

E-mail.Jiri.Kraft@tul.cz

cross $^{\text {ref }}$ http://dx.doi.org/10.5755/j01.ee.27.1.9734

Advanced market economies have not developed very successfully in recent years. The reason may lie in the inappropriate application of the economic theory conclusions by the authors of economic policies and, likewise on the economic theory part, assuming that it draws inadequate conclusions for the current economic reality.

The answer to the question of whether either of the above causes is relevant may be demonstrated in the phenomenon of market structures and their changes stimulated, inter alia, by the reality of economic integration. On the basis of a logical consideration of facts supported by graphic analysis, the following conclusion can be drawn: The changes in the economic reality on the part of the dominant oligopolies as well as on the part of the competitive fringe have not yet changed the conclusions formulated by the economic theory for the reality of the 1960s. Reviewing these theoretical economic conclusions and their adequacy for the current economic reality and the decision on whether the current economic policy should follow them are crucial. However, the example of the application of economic policy by the European Union and the Czech Republic - support for SMEs with the aim to increase the competition level - cannot be used for an a priori statement of inadequacy, neither on the application part nor on the economic policy formulation part.

Problems in economic development may, however, be caused by the entity called the "extent of thing". On the other hand, the fact that a minor problem was not found to be faulty, as shown by this article, does not mean that mistakes are not made in other, possibly more economically relevant, circumstances.

Keywords: Oligopoly, Monopoly, Competition, Dominant Company, Competitive Fringe.

\section{Introduction}

Advanced market economies do not appear to have been very successful recently, despite the current economic growth. It is, therefore, appropriate to ask the question of why. Whether the fault is on the part of economic theory applications in particular economic policies (Kraftova, Prasilova \& Mateja, 2011; Sedlacek et al., 2014) or on the part of economic theory itself not providing the authors of economic policies adequate conclusions for the reason that it was formulated for different economic conditions (Kraft, 2011; Reich, 1991).

To answer the above posed questions, it is possible to simply choose an economic phenomenon as an example and answer the question in the defined context. In this respect it is adequate to focus attention on a dynamically developing phenomenon which economic theory calls market structure forms.

The current condition of market structures at first sight appears constant. The reality of imperfect competition with its three elementary forms, monopolist competition, oligopoly and monopoly, has been omnipresent since the 19th century, and has substantially affected economic development (Baldwin \& Scott, 1987). All the three forms of imperfect economic competition are the same in many respects for their substance is identical, but their impact on macroeconomic development is significantly different (Dixit \& Stiglitz, 1977). There is the reasoning that in the context of monopolistic competition the position of every individual company as a price maker is the least usable against the consumer, but on the other hand the very reality of monopolistic competition is justly connected with the fact of the lowest level of the achieved technical-technologicaleconomic progress by every individual company of this market structure form. Monopoly is in the opposite situation (Farek, Kraft \& Zaytsev, 2013; Otahal, 2008).

The present article focuses on the form between the two mentioned above, the oligopoly, or in particular the oligopoly with a dominant company, with regard to changes within this form, or deflection of the current reality from the theoretical basis of oligopoly as formulated in the mid-20th century by George Stigler in his publication A Theory of Oligopoly of 1964 (Stigler, 1940) based in the period 193233 , when the term oligopoly was first introduced into modern economic theory by Joan Robinson (Robinson, 1954) and Edward Chamberlin (Chamberlin, 1950).

Elimination of the boundaries protecting domestic manufacturers reinforced the oligopoly structure in the context of the economies participating in the integration, for the to-date existing domestic monopolies merged with foreign monopolies through cartel agreements. However, in addition to these there has been a number of small and medium-sized companies which, together with big companies, have created oligopolies with dominant companies, in which there is not one dominant company, as assumed by economic theory, but more of them. SMEs, in addition, have been in the position of companies economically supported by the European Union and its Member States, and, therefore, their massive cessation is improbable (Geroski \& Gugler, 2004).

The above-mentioned consideration about the growing number of SMEs can be supported by statistical data when 
using the Czech Republic as an example. Economic development between the years 2007 and 2014 shows an increase in the total number of registered entities on the level of index 1.10; and yet in the case of micro companies with up to 5 employees - the phenomenon of competitive fringe to oligopoly with a dominant company - the base of 2007 on the level of 853,785 entities increased 1.24 times, while in the case of big companies with 500 to 2,000 employees with the baseline number 786 about 1.04 times, and even in the case of the biggest companies with more than 4,000 employees, in 2007 amounting to 40 entities - potential dominant companies of oligopolies, the increase was the greatest, with the index of 1.45. Other groups of registered entities classified according to the number of employees showed a decrease in the Czech Republic in the period in question (VDB CZSO, 2015). Although the level of participation of these groups of entities with this growth in the context of oligopoly with a dominant company can be neither confirmed nor denied on the basis of the available statistics.

The main purpose of the present contribution is to answer the question of whether under the condition of the nearly continental economic integration of Europe the conclusions of economic theory about oligopoly operation are correct, whether oligopolies have been able to adapt to the new conditions and whether the theoretical conclusions still remain applicable.

\section{Theoretical and Methodological Basis}

The present article is based on economic theory originating from the mid-20th century. This theory is applied in the article to the current economic reality with the help of graphic means allowing for the verbal considerations to be illustrated.

The applied research methods mainly include graphic mathematical methods, logical and to the necessary extent also statistical methods. The synthetic approach to the methods, which are accepted by theory and tested by practice, has led to the linking of elements of market structures - the cartel and elements of perfect competition into an oligopoly with a dominant company, which may bring new ideas to the existing economic theory.

First, the theoretical definition of oligopoly with a dominant company is reminded, in its modification for the present reality, where - also in the context of economic integration - the position of the "dominant company" is occupied by more than one of these entities. In one case the dominant companies are on an approximately identical technical-economic level, while in the other case the level is substantially different. Will these companies form an oligopoly with a dominant company together and will this lead to a cascade of this market structure, or will their combination result in a cartel? Posing this question under the current economic conditions is certainly legitimate.

After this introduction, the situation on the side of the competitive fringe is analysed, especially as this competitive fringe is advantaged in the EU by its support for SMEs, and therefore its weight grows.

The issue analysed in the present article is highly relevant today as the number of companies operating within this market structure is decisive, even in industries crucial for economic development (Jerbyshian, 2015; Cechura \& Sobrova, 2008). See for example the situation in electric energy generation in the Czech Republic, the relationships between CEZ on the side of the dominant entity, generating $70 \%$ of all electrical energy in the country, and another 1,500 participating companies on the side of the competitive fringe, including small hydro power plants, voltaic and wind power plants, among others. On the distribution side one can state that CEZ, E.ON and PRE share 90,000 consumers between them, i.e., $95 \%$ of end customers. The remaining 5 $\%$ of electricity is supplied to end customers in the Czech Republic by "independent vendors", numbering about 20 (UOHS, 2009). Can the abovementioned economic theory and its models be applied to this economic environment?

\section{Oligopoly with Dominant Company in Theory}

The theoretical consideration on which the model is based stems from the possible but currently not too frequently practically implemented variant of a single dominant company and a number of companies forming the competitive fringe. The dominant company then defines the optimum quantity produced in connection with the price optimal for the dominant company on the basis of equality of the limit income - derived from its mean income, or demand for its products - and its limit costs.

In addition to this dominant company there is a number of other companies of the competitive fringe, as if not belonging to this market structure, for these companies become passive recipients of the price - which is a fact of just perfect competition - accept the price defined by the dominant company and fill the vacant space in the market resulting from the difference between the total demanded quantity of production sold at the price defined by the dominant company and the total quantity produced by the dominant company - see Figure 1.

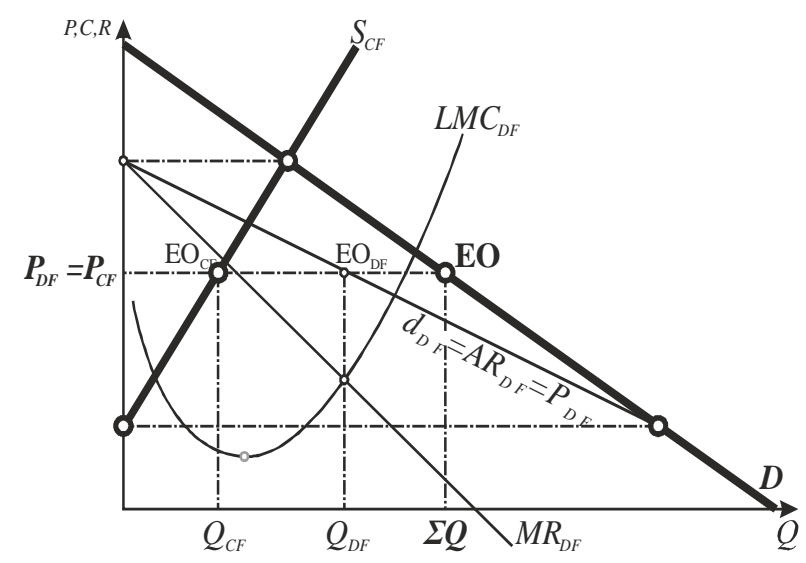

Figure 1. Oligopoly with a dominant company

\begin{tabular}{|c|c|c|c|}
\hline \multicolumn{4}{|c|}{ Key: } \\
\hline$P$ & price & LMC & long-term max. costs \\
\hline $\mathrm{C}$ & costs & EO & equilibrium \\
\hline $\mathrm{R}$ & revenues & AR & average revenues \\
\hline d & $\begin{array}{l}\text { demand for } \\
\text { company products }\end{array}$ & MR & max. revenues \\
\hline D & market demand & index $\mathrm{CF}$ & competitive fringe \\
\hline $\mathrm{S}$ & supply & index DF & dominant company \\
\hline
\end{tabular}

Source: Adapted from (Kraft, Bednarova \& Kocourek, 2011) 
There are several theoretical and practical issues connected with this model.

The first question is how the model or the real market situation will work when the position of the dominant company is not occupied by a single company, but rather two or even more different entities (Geroski, 1990). The second question is how the reality will address the situation of the competitive fringe where the companies are recipients of the price, i.e., in the position adequate to perfect competition, but the "taken over price" (defined by the dominant companies) does not guarantee them the saleability of all their products for they are not situated in an environment of perfect competition, and therefore this premise does not apply.

In this context there is the sub-question of whether the condition of maximisation of the profit of these companies by equality of limit revenues and limit costs may be met, and not only on the level of the competitive fringe as a whole, but also on the level of each individual member of the competitive fringe. At the same time, there is another interesting question to be answered, and that is how much of the production from the space of the competitive fringe left by the dominant companies will then be produced by each individual company, with the assumption that the technical-technological-economic standards of the competitive fringe companies may not be the same.

\section{Situation on the Side of Dominant Companies}

We will continue to assume that there is not one but more companies in the position of dominant company. Their typical feature is that their technical-technologicaleconomic level is substantially higher than that of the competitive fringe companies. However, at the same time, two variants are possible within the framework of the dominant companies (Bischi, Lamantia \& Radi, 2015).

The first assumes that the technical-technologicaleconomic level of all dominant companies is similar, while the other expects the level to differ considerably, while even the least technically-technologically-economically advanced company is much more advanced than any of the companies of the competitive fringe (Nickell, 1996).

The dominant companies of both of the abovementioned variants may be assumed to tend to agree together (about the price, the quantity of production, etc.). In the first case, where their technical-technologicaleconomic level is similar, they will form a price cartel in the context of which they will agree not to sell their products at prices lower than the agreed price level - see Figure 2.

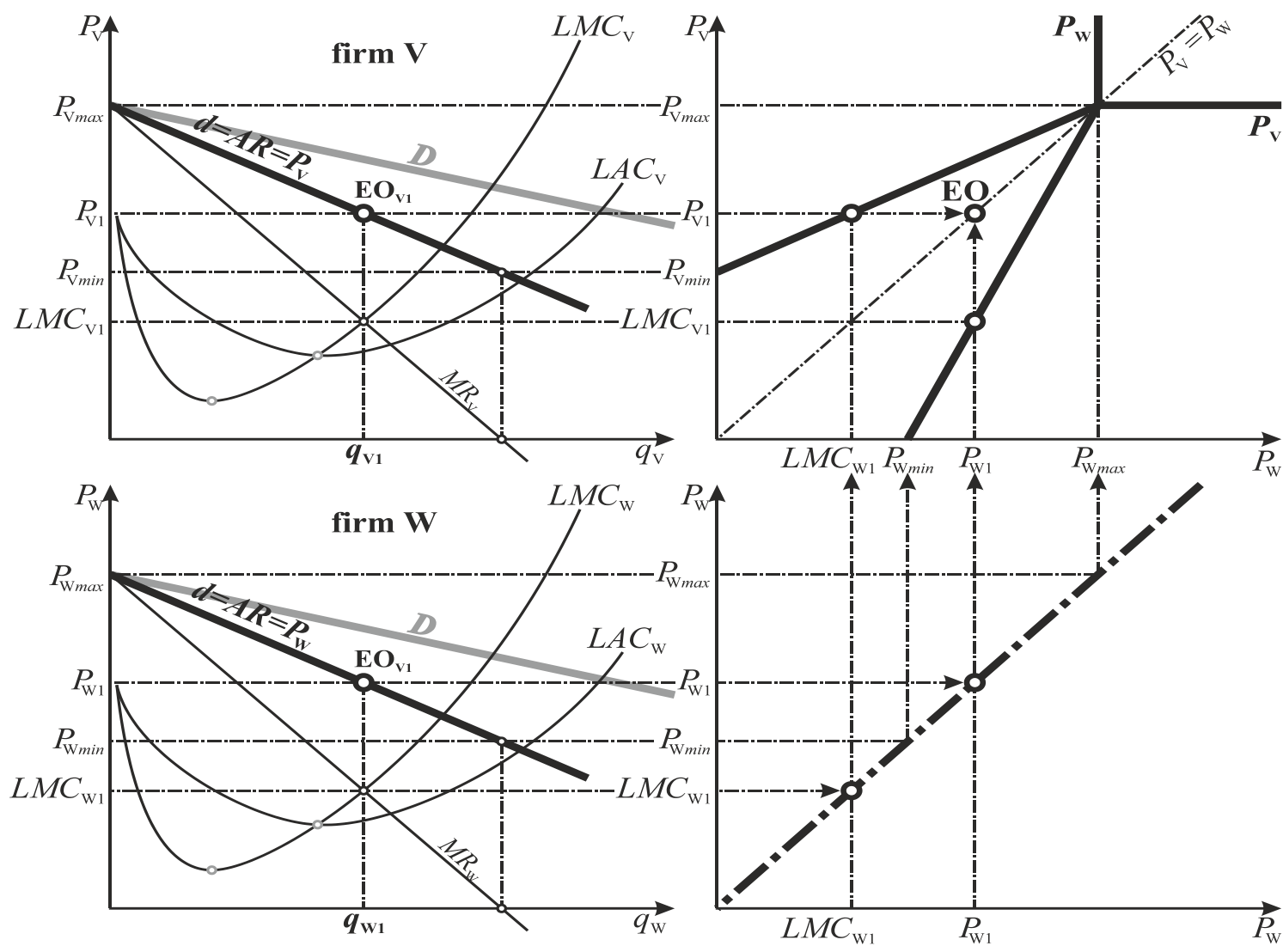

Figure 2. Price cartel

Key - see Figure 1 and in addition:

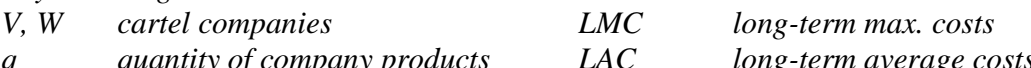

Source: Adapted from (Kraft, Bednarova \& Kocourek, 2011) 
In the case of the graphically expressed assumption of a duopoly, both participating dominant companies will produce one half of the products of the dominant companies each and they will agree on the same price, which will then be "imposed" on the competitive fringe companies. Despite the competition between the two dominant companies, the oligopoly will be stable on their side for the very reason of the agreed and mutually acceptable price and the quantity of products of each of them.

In the other case, when the technical-technologicaleconomic level of the dominant companies is not equal but rather differs significantly, there is also a solution (Kamien \& Schwartz, 1982). This variant is called quantity cartel see Figure 3.

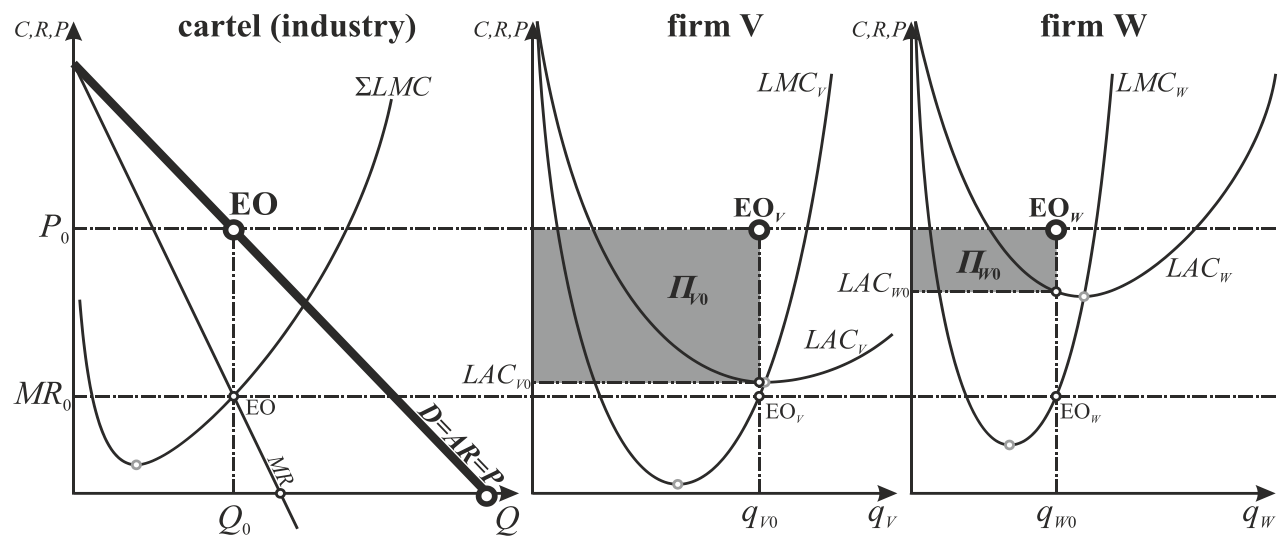

Figure 3. Quantity cartel

Key-see Figures 1, 2 and in addition:

$\Pi$ profit

Source: Adapted from (Kraft, Bednarova \& Kocourek, 2012)

Even in the quantity cartel the dominant companies will define a common price that will have to be accepted by the competitive fringe, but in this case the dominant companies will produce different quantities in a sum representing the dominant companies' products. There is, however, a question of whether the technicallytechnologically-economically less advanced dominant company will be willing to accept its not very advantageous position (low profit) in the long run. Another question arising in this context is whether such a cartel may be stable. What matters is whether the situation of the technically-technologically-economically less advanced company might improve if the company was positioned as one of the competitive fringe companies (Schrieves, 1978). Not exactly by "falling" among the competitive fringe companies where it would still be more technicallytechnologically-economically advanced than all of them, but by not co-creating the price but becoming its recipient. Figure 4 below shows that proceeding in such a way might not improve its situation, and that is why such a company may be expected to be willing to stay in the cartel despite the less advantageous position and not to create an oligopoly with a dominant company.

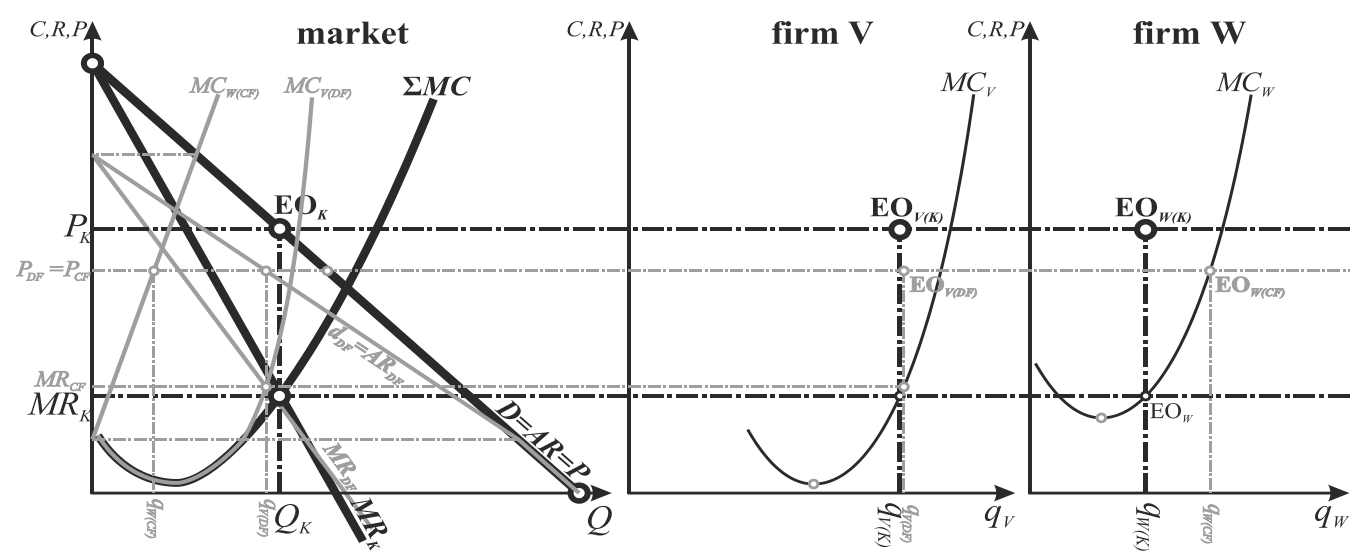

Figure 4. Change in position of dominant company in oligopoly

Key-see Figures 1, 2, 3 and in addition:

The grey dashed area marks the change in reality.

Source: Adapted from (Kraft, Bednarova \& Kocourek, 2011) 
The assumption is constant average costs assuring unchanged profit in the case of stable produced quantities. The fact that the economic reality is currently connected with more than one company co-creating the dominant company therefore does not substantially question the construction of oligopoly with a dominant company developed in the past century, and cannot therefore have any negative impact on its application in the current economic policy (Spence, 1975).

\section{Situation on the Competitive Fringe Side}

As mentioned above, the situation on the side of the competitive fringe is strongly non-standard. Companies of the competitive fringe are in the position of price recipients, on the one hand, and on the other they can only sell limited quantities of products at the dominant companies' imposed price.

If the price of products for the given reality is given, then the elasticity of demand for the company products equals infinity. The supply of each of the competitive fringe companies is given by their limit costs, or the growing part of this quantity from the point of activity completion. Interaction of the above-created supply and demand should therefore determine the quantity produced by each of the companies of the competitive fringe, which apparently does not resolve the problem for it is not clear how selection of the competitive fringe companies might be implemented in the situation when the sum of their products becomes higher than the space left for them by the decision of the dominant companies.

This non-resolvable situation cannot in fact happen in the practice of oligopoly with a dominant company for if production, or the number of companies in the competitive fringe, increases, then the sum of limit costs also increases. This fact will then determine demand for products of the dominant companies together with the limit revenues of these companies. That will lead to a new price and produced quantity specification with the price subsequently corresponding to the increased sum of costs of the competitive fringe caused by a different (in this case higher) volume of production by the competitive fringe companies - see Figure 5.

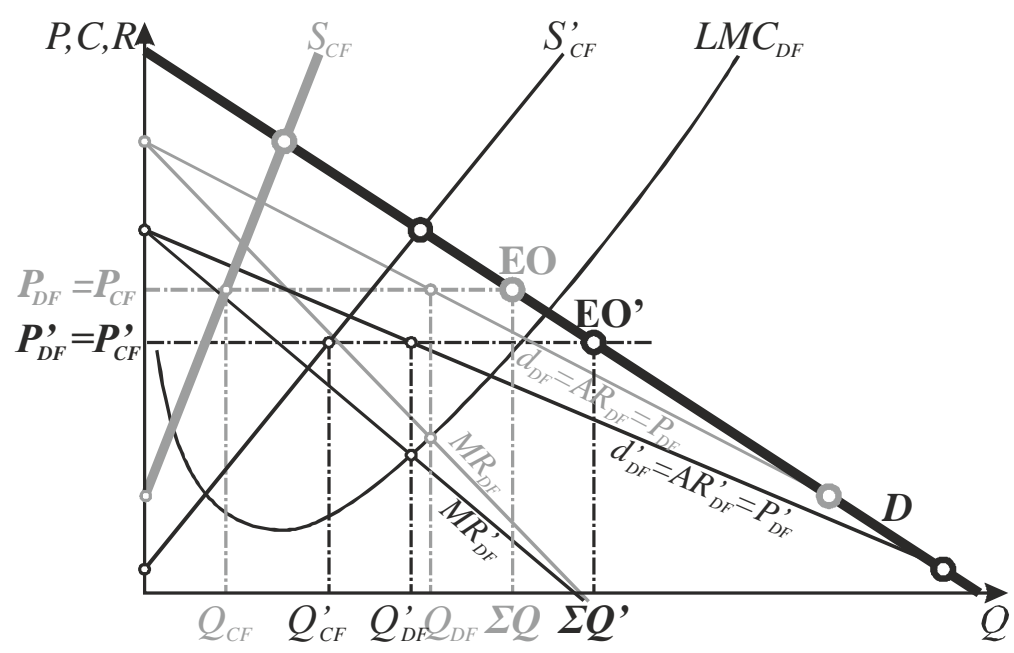

Figure 5. Quantity of products by competitive fringe companies and its potential change

Key - see Figures 1, 2, 3 and in addition:

The grey dashed area marks the change in reality.

Source: Adapted from (Kraft, Bednarova \& Kocourek, 2012)

There is always space for the sale of products by competitive fringe companies, with the quantity produced by each individual company of the competitive fringe directly related to its technical-technological-economic level (Zemplinerova, 2010). The concern regarding the impact of non-homogeneity of the environment of perfect and imperfect competition is therefore unjustified, and even in this case the conclusions of economic theory cannot be considered inadequate for economic policy formulation (Kraft, 2007).

The solution of the above-described issue can be considered crucial for the functionality of the oligopoly with a dominant company, for if this model works then the price created by it is ceteris paribus lower than the monopoly price and the produced quantity is higher. The frequency of occurrence of oligopolies with a dominant company is currently strongly affected by the loss of monopolistic position of the former national monopolies following the economic integration, or their transformation into the position of members of groups of dominant companies in the framework of the newly formed oligopolies. In the integration by expanded economic space the number of competitive fringe companies also grows, often with different levels of technical-technologicaleconomic standards, which is why this issue also had to be touched upon. What can be concluded from the above is 
that the oligopoly structure, quantitatively strengthened by economic integration, remains functional. And what is more, it has somewhat homogenised by the creation of another form of oligopoly on the side of the dominant companies in the context of the oligopoly with a dominant company, namely the cartel.

\section{Conclusions}

The existing economic reality of oligopoly with a dominant company, where unlike in the past, the dominant company environment is created by more than one company, and where in addition these numerous companies may show differing levels of technicaltechnological-economic advancement, like in the environment of the competitive fringe which can also be formed by equally or differently technicallytechnologically-economically advanced companies, has not been found in contradiction to the model base formed for the reality of the past century.

The modified concept of oligopoly with a dominant company may successfully function in the 21 st century with a positive impact on the economy in comparison to monopolies - lower price of products, higher produced quantities (Kraft, 2008). On condition that the number of dominant companies in the oligopolies is formed by the joined former national monopolies, the just concern of the handicap of a lower technical-technological-economic level connected with other forms of imperfect competition than monopoly will lose ground. The entry of former national monopolies into the number of dominant companies of oligopolies is not a reason for their technicaltechnological-economic advancement to be reduced.

At the beginning of this consideration, the question of whether the current condition of the relatively low level of success of advanced market economies might be caused by inadequate conclusions of economic theory in connection with the change in traditional oligopoly with a dominant company caused by economic integration within the European Union leading to an increase in the number of companies in the position of dominant company of an oligopoly was posed. The problem is not on the side of the competitive fringe companies operating in fact on the basis of perfect competition principles, either. Thus the changed economic conditions by way of economic integration not only did not cause economic problems in the context of market structure, but rather strengthened the functionality of oligopolies with a dominant company, which adapted to the new conditions and created original space for the functioning of cartels inside them.

\section{Acknowledgement}

This article could be written thanks to the generous support by the Grant Agency of the Czech Republic in the context of Project No. 402/09/0592 entitled "Development of Economic Theory in the Context of Economic Integration and Globalisation".

\section{References}

Baldwin, W. L., \& Scott, J. T. (1987). Market Structure and Technological Change. London: Harwood Academic Publishers.

Bischi, G. I., Lamantia, F., \& Radi, D. (2015). An evolutionary Cournot model with limited market knowledge. Journal of Economic Behavior \& Organization, 116(4), 219-238. http://dx.doi.org/10.1016/j.jebo.2015.04.024

Cechura, L., \& Sobrova, L. (2008). The price transmission in pork meat agri-food chain. Agric.Econ. - Czech. 54(2), 77-84.

Dixit, A. K., \& Stiglitz, J. E. (1977). Monopolistic Competition and Optimum Product Diversity. The American Economic Review, 67(3), 297-308.

Farek, J., Kraft, J., \& Zaytsev, A. (2013). High tech podniky v globalizovane znalostni ekonomice. (High tech companies in the globalized knowledge economy.) Liberec: Technical University in Liberec.

Geroski, P. A. (1990). Innovation, Technological Opportunity, and Market Structure. Oxford Economic Papers, 42, 586602

Geroski, P., \& Gugler, K. (2004). Corporate growth convergence in Europe. Oxford Economic Papers-New Series, 56(4), 597-620, http://dx.doi.org/10.1093/oep/gpf055

Chamberlin, R. (1950). The Theory of Monopolistic: a Re-Orientation of the Theory of Value. Cambridge: Harvard University Press.

Jerbyshian, V. (2015). The telecommunications industry and economic growth: How the market structure matters. Economic Modelling, 51, 515-523.

Kamien, M. I., \& Schwartz, N. L. (1982). Market Structure and Innovation. Cambridge: Cambridge University Press.

Kraft, J. (2007). Perspektivy firem oligopolniho lemu v podminkach ekonomicky se sjednocujici Evropy a jejich vliv na makroekonomicke veliciny. (Firm Perspectives of Oligopoly Hem in Condition of the Economically Integrating Europe and Their Influence on Macroeconomic Indicators.) Trendy ekonomiky a managementu. 1(1), 33-38.

Kraft, J. (2008). The Influence of the Oligopolistic Fringe on Economies of New EU Countries on the Example of the Czech Republic. Inzinerine Ekonomika - Engineering Economics, 5(60), 48-53.

Kraft, J., Bednarova, P. \& Kocourek, A. (2011). Mikroekonomie II. Liberec: Technical University in Liberec. 
Kraft, J. (2011). Market Structures and Macroeconomic Reality. Proceedings of the 10th International Conference Liberec Economic Forum, Liberec, 19. - 20. 9. 2011 (pp. 252-259). Liberec: Technical University in Liberec.

Kraft, J., Bednarova, P., \& Kocourek, A. (2012). Globalizace na prahu 21. stoleti. (Globalization on the threshold of the 21 st century.) Liberec: Technical University in Liberec.

Kraftova, I., Prasilova, P., \& Mateja, Z. (2011). High-tech Sector and the European Lagging in the Globalized Economy. Proceedings of the 10th International Conference Liberec Economic Forum, Liberec 19. - 20. 9. 2011 (pp. 284-294). Liberec: Technical University in Liberec.

Nickell, S. J. (1996). Competition and corporate performace. Journal of Political Economy, 104(4), pp. 724-746. http://dx.doi.org/10.1086/262040

Otahal, T. (2008). Teorie podnikatelskeho objevovani. (Theory of Entrepreneurial Discovery) Politicka ekonomie, 56, No. 5, 669-683. http://dx.doi.org/10.18267/j.polek.658

Reich, R. B. (1991). The Works of Nations. (Preparing Ourselves for 21th Century Capitalism). New York: A.A. Knopf.

Robinson, J. (1954). The economics of Imperfect Competition. London: Macmillan.

Sedlacek, J., Valouch, P., Hyblova, E., \& Krizova, Z. (2014). Changes in Property and Ownership Structure of Companies as a Consequence of Mergers in the Czech Republic. Inzinerine Ekonomika - Engineering Economics, 25(2), 152159. http://dx.doi.org/10.5755/j01.ee.25.2.4030

Schrieves, R. E. (1978). Market Structure and Innovation: A New Perspective. The Journal of Industrial Economics, 26(4), 329-347. http://dx.doi.org/10.2307/2098078

Spence, A. M. (1975). Monopoly, Quality, and Regulation. The Bell Journal of Economics, 6(2), $417-429$. http://dx.doi.org/10.2307/3003237

Stigler, G. J. (1940). Notes on the Theory of Duopoly. The Journal of Political Economy, 48, $377-397$. http://dx.doi.org/10.1086/255586

UOHS (Office for the Protection of Competition). (2009). Energetika. (Energetics.) Retrieved from http://www.compet.cz/fileadmin/user...listy/.../Infolist_2009_05_Energetika.pdf

VDB CZSO. (2015). Ekonomicke subjekty podle poctu zamestnanců. (Economic subjects by numbers of employees.) Retrieved from https://vdp.czso.cz/vdbvo2/faces/index. jsf?page=vystup-objekt\&z=t\&f=TABULKA

Zemplinerova, A. (2010). Inovacni activity firem a konkurence. (Innovation Activity of Firms and Competition). Politicka ekonomie, 58(6), 747-760. http://dx.doi.org/10.18267/j.polek.760

The article has been reviewed.

Received in January 2015; accepted in February, 2016. 